\title{
Determinan Kematian Neonatal Dini di RSUD Dr. Achmad Mochtar Bukittinggi
}

\author{
Efriza* $^{*}$
}

\begin{abstract}
Abstrak
Berdasarkan data SDKI 2002-2003 angka kematian neonatal di Indonesia adalah 20 per 1000 kelahiran hidup. Sebagian besar kematian neonatal terjadi pada saat neonatal dini ketika bayi berumur 0-7 hari. Penelitian ini bertujuan untuk mengetahui berbagai faktor yang mempengaruhi kematian neonatal dini di RSUD Dr. Achmad Mochtar Bukittinggi tahun 2001-2005. Penelitian yang dilakukan pada sumber data sekunder rekam medik ibu dan bayi ini menggunakan disain studi kasus kontrol. Sampel dihitung dengan rumus ukursan sampel minimal kasus kontrol. Kasus. adalah bayi yang lahir hidup dan meninggal pada periode neonatal dini (0-7 hari) dan kontrol adalah bayi yang lahir hidup dan bertahan hidup pada periode neonatal dini. Jumlah kasus:((93i) dan kontrol (392) ditentukan dengan rasio 1:4 untuk meningkatkan power penelitian Metoda analisis yang digunakan adalah analisis regresi logistik. Hasil penelitian menunjukkan kejadian kematian neonatal dini dipengaruhi oleh umur kehamilan, nilai apgar 1 menit setelah lahir, nilai apgar 5 menit setelah lahir dan berat lahir setelah dikontrol oleh variabel komplikasi kehamilan atau persalinan, rujukan, kelas perawatan, jenis persalinan, pendidikan ibu dan paritas. Bayi berat lahir sangat rendah (<1500 gram) berisiko untuk mati pada periode neonatal dini 59 kali lebih besar daripada bayi berat lahir normal. Sedangkan bayi berat lahir rendah (<2500 gram) berisiko mati pada periode neonatal dini 6 kali lebih besar daripada bayi berat lahir normal ( $\geq 2500$ gram). Antisipasi kematian neonatal dini perlu penanganan sejak kehamilan (ANC) sampai persalinan. Kerjasama pusat pelayanan dasar dengan pusat pelayanan ditingkat atas, persalinan di rumah sakit didampingi oleh dokter anak, pengkajian alat, tenaga, standar pelayanan dan mengoperasikan NICU (Neonatal Intensif Care Unit).

Kata kunci : Kematian neonatal dini, faktor risiko
\end{abstract}

\begin{abstract}
The Indonesia Demographic and Health Survey (SDKI) 2002-2003 reported neonatal death rate in Indonesia of 20 per 1000 live birth. Most of the neonatal death occurred early, that is in the age of infant of 0-7 days. This study aimed at knowing factors influencing early nenonatal detah in Dr Achmad Mochtar Hospital Bukittinggi in the year 2001-2005. The study used medical records of mother and infant as secondary data source and was designed as a casecontrol study. Cases were infants born alive and died during the early neonatal period ( $0-7$ days), and controls were infants born and stay alive during that period. Number of cases was 93 and control was 392 subjects was calculated on 1:4 ratio to increase the study power. Analysis method used was logistic regression analysis. The results show that early neonatal death was influenced by gestational age, Apgar score 1 minute after birth, Apgar score 5 minute after birth and birth weight after controlled by pregnancy or delivery complication, referral, health care class, type of delivery, mother's education, and parity variables. Infants with very low birth weight (<1500 grams) have 59 times greater risk of early neonatal death compared to those of normal birth weight. While those with low birth weight (<2500 grams) have 6 times greater risk compared to normal birth weight infants. To anticipate the occurrence of early neonatal death there is a need to intervene since pregnancy (through ANC) until delivery. There is also a need to foster the collaboration between different levels of health care facilities, delivery assistance by specialist in the hospital level, and to standardize health care process including Neonatal Intensive Care Unit (NICU) implementation.
\end{abstract}

Keywords : Early neonatal death, risk factors

*Staf Bagian Perencanaan RSUD Pariaman Sumatera Barat, JI. M. Yamin No. 5 Pariaman, Sumatera Barat (e-mail: eza_72@yahoo.com) 
AKI dan AKB merupakan indikator kesejahteraan suatu bangsa yang mencerminkan tingkat masalah kesehatan masyarakat. Millenium Development Goals (MDG) menyatakan bahwa tujuan keempat adalah menurunkan angka kematian anak usia di bawah lima tahun (balita) pada periode 1990 - 2015 sebesar dua pertiga. ${ }^{1}$ Pada rencana strategi nasional Making Pregnancy Safer (MPS) target dampak kesehatan bayi baru lahir adalah menurunkan angka kematian neonatal menjadi 15 per 1000 kelahiran hidup. $^{2}$

Sebagian besar kematian bayi terjadi pada masa neonatal (0-28 hari). Di Indonesia berdasarkan data SDKI 2002-2003 angka kematian bayi 35 per 1000 kelahiran hidup, sedangkan angka kematian neonatal adalah 20 per 1000 kelahiran hidup. ${ }^{3}$ Di Kabupaten Cirebon dari seluruh kematian neonatal $88 \%$ terjadi pada bayi berumur 0-7 hari. ${ }^{4}$ Lawn memperkirakan 38\% kematian balita terjadi pada masa $0-28$ hari setelah bayi lahir dan $75 \%$ dari kematian ini terjadi pada saat bayi berumur 0-7 hari. ${ }^{5}$ Angka kematian neonatal dini di RSUD Dr. Achmad Mochtar Bukittinggi adalah 79,19 pada tahun 2005.

Angka kematian neonatal dipengaruhi oleh berbagai faktor risiko seperti tingkat sosial ekonomi yang berhubungan dengan kelahiran bayi berat lahir rendah, mutu pelayanan pranatal, usia ibu, pekerjaan, paritas, status perokok ibu hamil, kelainan kehamilan, komplikasi persalinan, serta kondisi bayi seperti prematuritas, bayi berat lahir rendah (BBLR), asfiksia, dan infeksi. ${ }^{6}$ Faktor medik yang melatar belakangi kematian perinatal dan neonatal adalah usia ibu $<20$ tahun atau $>35$ tahun, paritas $>4$ orang dan jarak antar kehamilan $<2$ tahun. Komplikasi kehamilan, persalinan dan nifas merupakan penyebab langsung kematian ibu, perinatal dan neonatal, seperti perdarahan per vaginam, infeksi, preeklamsia / eklamsia, komplikasi akibat partus lama, dan trauma persalinan. ${ }^{7}$

Pola penyebab utama kematian neonatal di Indonesia tidak jauh berbeda dengan pola penyebab utama kematian neonatal di dunia, yaitu prematuritas / BBLR $(27 \%)$, asfiksia (23\%), sepsis /pneumonia (26\%), tetanus $(7 \%)$, diare $(3 \%)$, kelainan kongenital $(7 \%) .5$ Dari kajian pengadaan pelayanan kegawat-daruratan obstetrik dan neonatal di tiga rumah sakit di Kabupaten Serang diketahui bahwa penyebab kematian neonatal adalah BBLR $(45,76 \%)$, asfiksia $(29,66 \%)$, infeksi $(0,42 \%)$ dan lain-lain $(24,15 \%) .{ }^{8}$ Masa awal kehidupan bayi menjadi saat yang paling kritis bagi bayi-bayi yang berisiko tinggi. Deteksi dini berbagai faktor risiko tinggi pada ibu dan neonatus akan sangat membantu pemantauan dan pengobatan yang cepat dan tepat. Tujuan pendekatan antisipasi dan intervensi aktif adalah untuk mencegah perkembangan dan progresivitas penyakit dan mengurangi kecacatan dan kematian pada neonatus risiko tinggi. ${ }^{9}$

Tujuan penelitian ini adalah mengetahui berbagai faktor yang mempengaruhi kematian neonatal dini di RSUD Dr. Achmad Mochtar Bukittinggi tahun 2001-2005. Hasil penelitian diharapkan dapat dijadikan masukan bagi rumah sakit dan para pengambil keputusan di bidang kesehatan dalam upaya meningkatkan kualitas pelayanan kesehatan ibu dan bayi baru lahir.

\section{Metode}

Penelitian dengan desain studi kasus kontrol ini dilakukan di RSUD Dr. Achmad Mochtar Bukittinggi pada periode 2001-2005. Kasus adalah bayi yang lahir hidup dan meninggal pada periode neonatal dini (0-7 hari). Kontrol adalah bayi yang lahir hidup dan masih hidup pada periode neonatal dini. Populasi adalah semua bayi yang lahir hidup. Ukuran sampel minimal dihitung dengan rumus sampel disain kasus kontrol.

$$
\begin{aligned}
& \mathrm{m}=\frac{\left[\mathrm{Z}_{1-\alpha / 2} \sqrt{(1+1 / k) P(1-P)}+\mathrm{Z}_{1-\beta} \sqrt{P 1(1-P 1)+(P 2(1-P 2) / k}{ }^{2}\right]}{\left(P_{1}-P_{2}\right)^{2}} \\
& P=\frac{\frac{\left(P_{1}+k P_{2}\right)}{(1+k)}}{P_{1}=\frac{(\mathrm{OR}) P_{2}}{(\mathrm{OR}) P_{2}+\left(1-P_{2}\right)}}
\end{aligned}
$$

Dengan nilai $p=0,14 \alpha=5 \%$ dan $1-\beta=80 \%$ didapatkan jumlah kasus dan kontrol adalah 110. Mengingat jumlah kasus kematian neonatal dini (93) adalah lebih kecil dari jumlah sampel minimal maka untuk memperbesar power, jumlah kontrol ditingkatkan dengan rasio 1:4. Dengan demikian, sampel pada penelitian ini meliputi kasus (93 bayi) dan kontrol (392 bayi). Variabel yang diamati pada penelitian ini meliputi variabel dependen kematian neonatal dini dan berbagai variabel independen yang mempengaruhinya. Variabel independen tersebut meliputi faktor ibu (umur, pendidikan, paritas), faktor kehamilan dan persalinan (umur kehamilan, komplikasi kehamilan atau persalinan dan jenis persalinan), faktor bayi (jenis kelamin, berat lahir, nilai apgar 1 dan 5 menit setelah lahir dan kelainan kongenital), faktor sosial ekonomi (kelas perawatan) dan faktor pelayanan kesehatan (rujukan).

Analisis yang dilakukan dengan metode regresi logistik ganda. Variabel yang masuk dalam model multivariat ditentukan berdasarkan hasil regresi bivariat dengan nilai $\mathrm{p}<0,25$. Tahap berikutnya adalah evaluasi hasil regresi logistik multivariat dengan melihat nilai uji statistik 
Tabel 1. Rangkuman Hasil Analisis Bivariat untuk Seleksi Kandidat Model Multivariat Kematian Neonatal Dini

\begin{tabular}{|c|c|c|}
\hline Variabel & Katagori & Nilai p \\
\hline Umur Ibu & $<20$ th / >35th & 0,461 \\
\hline Pendidikan Ibu & $\mathrm{SD}$ & 0,004 \\
\hline Paritas & 1 dan $\geq 4$ & 0,008 \\
\hline Umur Kehamilan & $<37$ atau $\geq 42 \mathrm{mgu}$ & $<0,001$ \\
\hline Preeklamsi/eklamsi & ya & 0,067 \\
\hline Perdarahan & ya & $<0,0$ \\
\hline KPD & ya & 0,035 \\
\hline Partus Lama & ya & $<0,001$ \\
\hline Presentasi janin & Bukan Kepala & 0,605 \\
\hline Komplikasi & yа & $<0,001$ \\
\hline Jenis persalinan & Eks vakum/forcep & $<0,001$ \\
\hline Jenis Kelamin & Perempuan & 0,105 \\
\hline Apgar 1 menit & $0-3$ & $<0,001$ \\
\hline Apgar 5 menit & $0-3$ & $<0,001$ \\
\hline Berat Lahir & $\geq 2500$ gram & $<0,001$ \\
\hline Kelas Perawatan & Kelas III & $<0,001$ \\
\hline Rujukan & Ya & $<0,001$ \\
\hline Kelas Perawatan & Kelas I dan II & $<0,001$ \\
\hline
\end{tabular}

wald untuk masing-masing variabel dengan menggunakan $\alpha=0,05$ dan juga evaluasi menurut substansi keilmuan. Variabel yang memiliki nilai $p>0,05$ dikeluarkan dari model. Evaluasi dilakukan dengan membandingkan koefisien masing-masing kovariat dengan dan tanpa kovariat yang dikeluarkan, jika terdapat perbedaan koefisien yang cukup besar $(>10 \%)$ maka variabel tersebut tidak dapat dikeluarkan dari model karena akan mengganggu estimasi koefisien kovariat lainnya. Evaluasi interaksi dilakukan dengan melihat nilai p pada uji Wald, nilai $p>0,05$ dikeluarkan dari model. Lakukan evaluasi ulang dengan uji likelihood ratio $(\alpha=0,05)$, jika terdapat interaksi $(\mathrm{p}<0,05)$ maka variabel-variabel interaksi tersebut harus selalu dimasukkan kedalam suatu model yang mengandung komponen faktor-faktor risiko pada model yang bersangkutan.

\section{Hasil \\ Seleksi Variabel Kandidat Model}

Seleksi kandidat model dilakkan dengan analisis bivariat. Variabel dinyatakan masuk ke dalam kandidat model jika memenuhi kreteria nilai p uji chi square $\leq$ 0,25 . Terlihat bahwa variabel yang tidak memenuhi kriteria tersebut adalah variabel umur ibu dan presentasi janin. (Lihat tabel 1).

\section{Analisis Multivariat}

Dari model multivariat akhir terlihat bahwa variabel yang berhubungan dengan kematian nenatal dini di RS Dr Achmad Mochtar Bukit Tinggi, tahun 2001-2005 adalah umur kehamilan, apgar skor 5 menit, dan berat badan lahir. Bayi yang lahir dengan umur kehamilan prematur berisiko 3,94 kali lebih besar untuk mengalami kematian neonatal daripada yang bayi yang matur (OR 3,94, nilai p 0,033, 95\% CI OR = 1,12-13,89). Bayi yang lahir dengan nilai Apgar skor 5 menit 4-6 dan 0-3 berisiko kematian neonatal dini 3,62 dan 35,73 kali lebih besar untuk mengalami kematian neonatal dini daripada bayi dengan nilai Apgar Skor 5 menit 7-10. (OR 3,62, nilai p 0,004, 95\% CI OR $=1,02-12,8$ ). Bayi dengan berat badan lahir $1500-2499$ gr dan < 1500 gram berisiko mengalami kematian neonatal 6,15 dan 58,7 kali lebih besar daripada bayi dengan berat badan $>2500$ gram (normal) (OR 6,15, nilai p 0,001, 95\% CI OR = 1,82-20,77); (OR 56,7, nilai p 0,001, 95\% CI OR =

Tabel 2. Model Multivariat Akhir Kejadian Kematian Neonatal Dini di RSUD Dr Acmad Mochtar Bukit Tinggi Tahun 2001-2005

\begin{tabular}{|c|c|c|c|c|c|}
\hline Variabel & Katagori & B & Nilai p & Rasio Odd & $95 \%$ CI OR \\
\hline Umur Kehamilan & Prematur & 1,37 & 0,033 & 3,94 & $1,12-13,89$ \\
\hline \multirow[t]{2}{*}{ Apgar 1 menit } & $4-6$ & 0,991 & 0,077 & 2,69 & $0,71-10,24$ \\
\hline & $0-3$ & 2,418 & & 11,23 & $1,39-90,96$ \\
\hline \multirow[t]{2}{*}{ Apgar 5 menit } & $4-6$ & 1,286 & 0,004 & 3,62 & $1,02-12,8$ \\
\hline & $0-3$ & 3,574 & & 35,75 & $4,24-30086$ \\
\hline Komplikasi & Ya & 0,336 & 0,503 & 1,4 & $0,52-3,75$ \\
\hline Rujukan & Ya & 0,336 & 0,465 & 1,4 & $0,55-3,59$ \\
\hline \multirow{2}{*}{ Kelas Perawatan } & Kelas I \& II & $-0,902$ & 0,585 & 0,41 & $0,05-3,27$ \\
\hline & Kelas III & $-0,488$ & & 0,61 & $0,06-6,011$ \\
\hline \multirow[t]{2}{*}{ Jenis Perrsalinan } & Secsio Cesaria & $-0,009$ & 0,591 & 0,99 & $0,34-2,91$ \\
\hline & Vakum/ Forsep & 0,702 & & 2,02 & $0,51-8,02$ \\
\hline Paritas & $1 \& \geq 4$ & 0,767 & 0,112 & 2,15 & $0,84-5,55$ \\
\hline Konstant & & $-4,209$ & 0 & 0,02 & - \\
\hline
\end{tabular}




\section{7,14-482,86). (Lihat tabel 2)}

\section{Pembahasan}

Kematian neonatal dini (0-7 hari) dapat dilhat dari faktor penyebab dan faktor pencegah yang berpengaruh. Penyebab kematian neonatal dini di RSUD Dr. Achmad Mochtar Bukittinggi adalah asfiksia $(47,3 \%)$, bayi berat lahir rendah $(36,6 \%)$, respiratory distress syndrome $(8,6 \%)$ dan lain-lain $(7,5 \%)$. Sekitar $49,5 \%$ kematian neonatal terjadi pada periode neonatal dini yaitu dalam waktu kurang dari 24 jam setelah melahirkan.

\section{Faktor Ibu}

Penelitian ini tidak menemukan hubungan yang bermakna antara umur ibu dengan kematian neonatal dini $(p>0,05)$. Bayi yang dilahirkan oleh ibu yang berumur kurang dari 20 dan lebih dari 35 tahun berisiko untuk mati pada periode neonatal dini 1,2 kali lebih besar daripada bayi dengan ibu yang berumur 20-35 tahun. Temuan ini sesuai dengan hasil penelitian di Kabupaten Bandung tahun 2001.10 Namun, beberapa penelitian menemukan hubungan yang erat antara umur ibu pada saat melahirkan dengan kematian perinatal (neonatal dini). ${ }^{11,12}$ Perbedaan temuan penelitian tersebut kemungkinan disebabkan oleh ukuran sampel yang kecil, mengingat hubungan kedua variabel yang amat rendah.

Pendidikan tampaknya merupakan faktor, semakin tinggi tingkat pendidikan ibu semakin kecil risiko kematian neonatal dini. Hal tersebut sesuai dengan hasil penelitian yang dilakukan terhadap data SDKI tahun 20022003. ${ }^{13}$ Ibu yang berpendidikan formal atau informal rendah mengalami kesulitan menerima informasi kesehatan dan memilih fasilitas pelayanan kesehatan yang tepat untuk memeriksakan kehamilan. Selain itu mereka kurang bisa mengatur konsumsi makanan yang sesuai dengan kebutuhan sehingga terjadi kekurangan zat gizi dan anemia yang pada akhirnya menyebabkan komplikasi kehamilan atau persalinan yang berakibat pada kematian. Hal ini dapat diatasi dengan meningkatkan penyuluhan-penyuluhan serta pelatihan-pelatihan bagi ibu hamil dalam menjaga dan mengurus kehamilannya.

Bayi yang dilahirkan oleh ibu dengan paritas 1 dan $\geq$ 4 orang berisiko mengalami kematian neonatal dini 1,89 kali lebih besar (95\% CI OR: 1,17-3,06) daripada bayi yang dilahirkan oleh ibu dengan paritas 2-3. Hasil ini sesuai dengan penelitian di Kotamadya Bengkulu dan di Kabupaten Indra Giri Hulu. ${ }^{11,12}$ Risiko kematian neonatal dini yang besar pada pada bayi yang dilahirkan dari ibu dengan paritas satu disebabkan oleh kekakuan jaringan panggul serta pengetahuan tentang perawatan kehamilan dan persalinan yang rendah. Pada ibu dengan paritas $>3$, kematian neonatal dini dapat disebabkan oleh kemunduran elastisitas jaringan yang sudah berulang kali berkontraksi pada saat persalinan sehingga membatasi kemampuan menghentikan pendarahan. Hal ini dapat menyebabkan pendarahan hebat pada saat persalinan dan membawa risiko pada kematian bayi.

Bayi yang dilahirkan dengan umur kehamilan $<37$ minggu dan $\geq 42$ minggu berisiko mengalami kematian neonatal dini 12,97 kali (95\% CI OR: 7,50-22,43) lebih besar dari pada bayi dengan umur kehamilan 37-41 minggu. Penelitian ini sesuai dengan penelitian di lima Rumah Sakit di Yogyakarta, bayi dengan usia kehamilan kurang 37 minggu berisiko mengalami kematian periode perinatal 9,08 kali lebih besar daripada bayi dengan umur kehamilan 37-41 minggu. ${ }^{14}$ Masa kehamilan yang makin pendek makin kurang sempurna pertumbuhan organ tubuh bayi sehingga makin mudah terjadi komplikasi dan kematian. Bayi kurang bulan tidak dapat menghisap dan menelan secara sempurna sampai usia gestasi diatas 32 minggu, pemenuhan kebutuhan makanan pada usia 1-2 minggu pertama lambat dicapai. Bayi kurang bulan membutuhkan perhatian khusus tentang cara, jenis dan jumlah makanan yang diberikan. ${ }^{15}$ Bayi kurang bulan rentan terhadap hipotermi, disamping karena kemampuan memproduksi panas yang kurang juga karena mudah kehilangan panas. Kehilangan panas tubuh yang cepat karena daerah permukaan tubuh yang luas khususnya jika tidak segera dikeringkan. Hipotermia neonatal akan terjadi lebih parah jika bayi kurang bulan, karena kekurang lemak coklat (brown fat) yang membantu mempertahankan suhu tubuhnya. Gejala menggigil berlebihan akan membuat bayi kehabisan energi serta oksigen dan jika suhu tubuh turun hingga dibawah $35^{\circ} \mathrm{C}$ akan terjadi cedera neonatal akibat dingin (neonatal cold injury) yang dapat menyebabkan kematian. ${ }^{16}$

\section{Faktor Kehamilan dan Persalinan}

Risiko kematian neonatal dini pada bayi yang dilahirkan oleh ibu dengan komplikasi kehamilan atau persalinan adalah 4,30 kali lebih besar (95\% CI OR 2,48-7,46) daripada bayi yang dilahirkan oleh ibu yang tidak mengalami komplikasi kehamilan atau persalinan. Temuan tersebut sesuai dengan beberapa penelitian yang dilakukan di Bandung, Keruak NTB dan di Yogyakarta. 10,14,17 Komplikasi kehamilan atau persalinan merupakan kondisi patologis yang secara langsung menyebabkan kesakitan dan kematian ibu dan bayi yang tidak selalu dapat diperkirakan sebelumnya, sehingga ibu hamil perlu berada dekat dengan sarana pelayanan yang mampu memberikan pelayanan obstetri dan neonatal emergensi dasar (PONED). Untuk mendukung Puskesmas yang mampu PONED RSU Kabupaten/Kota diharapkan mampu melaksanakan pelayanan obstetri dan neonatal emergensi komprehensif (PONEK) selama 24 jam. Puskesmas yang mampu PONED dan rumah sakit yang mampu PONEK memungkinkan berbagai kasus komplikasi kehamilan atau persalinan ditangani secara optimal sehingga dapat 
menurunkan kematian ibu dan bayi baru lahir. ${ }^{18}$ Aspek neonatus perlu ditangani dengan kegiatan perawatan neonatal secara intensif oleh bidan atau perawat yang terlatih menangani kegawatan setiap saat.

Persalinan ekstraksi vakum adalah persalinan buatan yang melahirkan bayi dengan melakukan ekstraktsi vakum yang menarik kepala bayi. Ekstraksi vakum merupakan faktor penyebab trauma mekanik utama pada kepala bayi, dan dikenal sebagai penyebab langsung kerusakan pembuluh darah intrakranial. Hal tersebut merupakan salah satu faktor penyebab utama kesakitan dan kematian pada periode neonatal. Dengan demikian, persalinan ekstraksi vakum seharusnya dilakukan berdasarkan indikasi. ${ }^{19}$ Persalinan mungkin memerlukan tindakan operatif yang dilakukan pada keadaan umum yang baik dan keadaan umum kurang baik dan buruk. ${ }^{20}$ Kematian neonatal dini pada bayi yang dilahirkan dengan tindakan bukan semata-mata karena tindakan yang dilakukan tetapi juga karena faktor ibu, faktor bayi atau faktor kehamilan.

\section{Faktor Bayi}

Pada periode neonatal dini bayi masih dalam pengawasan medis dan belum terpajan dengan faktor luar, belum ada pengaruh makanan dan belum ada intervensi ibu/keluarga. Dengan demikian, belum ada perbedaan perlakuan misalnya akibat perbedaan gender yang akan berpengaruh pada kematian bayi. Penelitian ini menemukan hubungan yang bermakna antara nilai apgar 1 menit dan 5 menit setelah lahir dengan kematian neonatal dini $(p<0,001)$. Pada Kajian pelayanan kegawat daruratan obstetrik dan neonatal di RSUD Kabupaten Serang menemukan bahwa sekitar 113 kematian neonatal $(61,95 \%)$ disebabkan oleh asfiksia. ${ }^{8}$ Penelitian di Port Moresby General Hospital berdasarkan nilai apgar 5 menit setelah lahir, sebanyak 31 kematian neonatal (87\%) mati dengan nilai apgar $\leq 6$ dan 18 diantaranya mati pada umur $<24$ jam. Juga ditemukan faktor risiko asfiksia yang lain yaitu berat bayi $<2000$ gram. ${ }^{21}$

Penelitian di Rumah Sakit Umum Ulin Banjarmasin menemukan bahwa BBLR meningkatkan risiko kejadian asfiksia 2,86 kali lebih besar daripada bayi yang berat badan normal. BBLR ternyata sangat peka terhadap perubahan suhu lingkungan, kekurangan oksigen, infeksi, komponen makanan yang tidak sesuai, serta trauma. ${ }^{22}$ Pada beberapa keadaan asfiksia waktu lahir dapat dideteksi dengan riwayat partus lama, kelahiran prematur dan infeksi intra partum. Dampak asfiksia akan bertambah buruk jika penanganan bayi tidak dilakukan secara sempurna. Untuk mencegah berbagai kejadian yang tidak diinginkan tersebut, prinsip-prinsip penanganan neonatus yang baik harus terus ditingkatkan. Penelitian ini menemukan hubungan yang bermakna antara berat lahir dengan kematian neonatal dini $(\mathrm{p}<0,001)$. Temuan ini sesuai dengan hasil penelitian di Yogyakarta dan di Kecamatan Kerua, NTB. ${ }^{14,17}$ Kajian pengadaan pelayanan kegawat daruratan obstetrik dan neonatal di Kabupaten Serang menemukan 17,7 \% dari 113 kematian neonatal di RSUD Serang disebabkan oleh berat lahir rendah. ${ }^{21}$ Penelitian di Rumah Sakit Kanujoso Djatiwibowo (RSKD) Balikpapan menemukan 52,42\% bayi BBLR mengalami kematian neonatal. ${ }^{23}$

Bulan pertama pasca persalinan merupakan masa transisi bagi bayi baru lahir dengan waktu yang paling kritis adalah minggu pertama setelah lahir. Untuk itu, diperlukan perhatian khusus dan asuhan yang intensif pada bayi baru lahir pada periode tersebut. BBLR adalah masalah kompleks yang memerlukan penanganan multi sektor. Penanganan BBLR tersebut meliputi pengaturan suhu lingkungan, pemberian makan dan jika perlu pemberian oksigen. BBLR merupakan penyumbang terbanyak kematian bayi neonatal, sementara fasilitas rumah sakit di negara berkembang masih terbatas. Metoda alternatif yang dapat digunakan untuk mengatasi keterbatasan dalam merawat BBLR adalah menggunakan metoda kanguru. Proses penyesuaian metoda kanguru ini dirumah sakit bertujuan agar ibu dan bayi siap untuk menerima metoda ini dan selanjutnya menggunakannya untuk perawatan dirumah. ${ }^{24}$

Pengawasan antenatal yang baik merupakan faktor penting yang berkontribusi besar terhadap penurunan kelahiran bayi berat lahir rendah. Faktor sosial ekonomi berpengaruh terhadap kematian neonatal dini. Status sosial ekonomi yang rendah berpengaruh terhadap berat badan lahir melalui asupan gizi ibu hamil yang kurang. Keadaan ini akan berpengaruh pada pertumbuhan dan perkembangan janin. Ibu dengan tingkat ekonomi yang rendah biasanya tidak melakukan pemeriksaan antenatal secara lengkap dan baik. Sistem rujukan pelayanan obstetri adalah suatu pelimpahan tanggung jawab timbal balik terhadap kasus-kasus kebidanan yang terjadi. Pemahaman berbagai faktor risiko dapat menurunkan angka kematian dan kesakitan. Berbagai kasus kegawatan obstetrik perinatal sering terlambat sampai ke rumah sakit dan dalam keadaan umum yang sangat jelek, sehingga jiwa ibu dan bayinya tidak dapat diselamatkan, meskipun dengan sarana dan fasilitas yang lengkap. Dengan demikian, keberhasilan proses kehamilan dan persalinan tidak semata-mata ditentukan oleh sarana dan tenaga yang baik tetapi juga pada kesadaran dan prilaku penderita dan masyarakat.

Rumah sakit kabupaten/kota merupakan pusat rujukan medis, kesehatan dan teknologi bagi fasilitas kesehatan di wilayahnya. Puskesmas dan bidan perlu ditingkatkan kemampuan menangani kegawatan obstetrik-neonatal melalui pembinaan teknis dari rumah sakit setempat secara berkelanjutan. Hal tersebut dilakukan melalui pelatihan, magang, rujukan kasus, dan 
audit kematian/kesakitan maternal dan neonatal. Kasus yang perlu penangan intensif harus dirujuk ke fasilitas yang lebih lengkap. Di samping itu, pelayanan kesehatan ibu ketika hamil, perawatan kehamilan dan beberapa jam setelah persalinan berisiko meningkatkan kejadian kematian neonatal dini.

\section{Kesimpulan}

Untuk itu, diperlukan perhatian khusus dan asuhan yang intensif pada bayi baru lahir pada periode tersebut. BBLR adalah masalah kompleks yang memerlukan penanganan multi sektor.

Kejadian kematian neonatal dini dipengaruhi oleh umur kehamilan, nilai apgar 1 menit setelah lahir, nilai apgar 5 menit setelah lahir dan berat lahir dikontrol oleh variabel komplikasi kehamilan atau persalinan, rujukan, kelas perawatan, jenis persalinan, pendidikan ibu dan paritas. Faktor risiko yang paling mempengaruhi kematian neonatal dini di RSUD Dr. Achmad Mochtar Bukittinggi adalah berat lahir dikontrol oleh faktor risiko yang lain. Untuk mengurangi risiko kematian neonatal dini maka perlu penanganan sejak kehamilan (ANC) sampai setelah persalinan (penatalaksanaan neonatus), kerjasama pusat pelayanan dasar dengan pusat pelayanan ditingkat atas, persalinan di rumah sakit didampingi oleh dokter anak, pengkajian alat, tenaga, standar pelayanan dan mengoperasikan NICU (Neonatal Intensif Care Unit).

\section{Saran}

Berdasarkan temuan penelitian, disarankan perlu penanganan kegawatan neonatus dengan kegiatan perawatan neonatal secara intensif setiap saat oleh bidan atau perawat yang terlatih. Berbagai tidakan obstetrik khususnya yang berisiko mencederai bayi dilakukan secara sangat ketat semata-mata berdasarkan indikasi. Penanganan BBLR harus dilakukan secara baik kerena bukan saja berkontribusi besar pada penurunan angka kematian neonatal dan kematian bayi tetapi juga meningkatkan kualitas hidup bayi pada masa yang akan datang. Beberapa faktor yang perlu mendapat perhatian serius adalah peningkatan pelayanan ANC di pelayanan kesehatan tingkat dasar dan di rumah sakit dengan cara memberikan konseling perawatan dan persiapan persalinan, tanda-tanda bahaya kehamilan atau persalinan, serta pola asupan gizi ibu hamil dan keluarga yang mendampingi.

\section{Daftar Pustaka}

1. The United Nations Department of Public Information: The Millenium Development Goals and The United Nations Role, October 2002

2. Depkes, Rencana Strategis Making Pregnancy Safer (MPS) di Indonesia 2001 -2010. Jakarta: Depkes RI dan WHO, 2001

3. BPS. Survey Demografi dan Kesehatan Indonesia 2002-2003. Jakarta:
BPS, 2003

4. Kosen dan Djaya. Base Line Survey on Neonatal Mortality (Verbal Autopsy) at Cirebon District Year 2004. Jakarta: National Institute of Health Research \& Development, 2004

5. Lawn, Joy E, Simon Cousens \& Jelka Zupan. Four Million Neonatal Deaths: When? Where?Why? http:/image.thelancet.com/extras/ 05art1073web.pdf. Published online March 3, 2005

6. Narendra. Buku Ajar Tumbuh Kembang Anak \& Remaja. Jakarta: CV. Sagung Seto, 2005

7. Depkes, Pedoman Teknis Audit Maternal-Perinatal di Kabupaten/Kota. Jakarta: Depkes RI, 2003

8. Setiarini, Asih. Kajian Pengadaan Pelayanan Kegawatdaruratan Obstetrik dan Neonatal di Kabupaten Serang. Jakarta: Depkes RI, WHO, 2003

9. Klaus, Marshall H \& Avroy A. Fanaroff editor: Surjono, Achmad Care of the High-Risk Neonate (Penatalaksanaan Neonatus Resiko Tinggi). Jakarta: EGC, 1998

10. Kustijadi, Achmad. Hubungan Pelayanan Antenatal dengan Kejadian Kematian Perinatal di Kabupaten Bandung Tahun 2001(Tesis). Depok: FKM UI, 2002

11. Junita, Evy Irma. Hubungan Antara Pelayanan Antenatal dengan Kematian Perinatal di Kabupaten Indera Giri Hulu Tahun 2002 (Tesis). Depok: FKM UI, 2003

12. Lubis, Yuliana. Faktor-faktor yang Mempengaruhi Kematian Perinatal di Kotamadya Bengkulu Tahun 2000-2001 (Tesis). Depok: FKM-UI, 2001

13. Sudarto, Sudiardini. Hubungan Faktor Sosio Demografi terhadap Pengalaman Kematian Neonatus Ibu di Indonesia 1998-2002(Analisis Data Sekunder Data SDKI 2002-2003) (Skripsi). Depok: FKM UI, 2005

14. Haksari, Ekawaty L dan Achmad Surjono. Resiko Kematian Perinatal Pada Primipara di Lima Rumah Sakit Daerah Tingkat II di Yogyakarta. Berkala Ilmu Kedokteran Vol. 33 No. 4, 2001, 199-206

15. Amir, Idham, Rinawati Rohsiswatmo, Risma Kerina K. Penatalaksanaan Bayi Berat Lahir Rendah. Medan: Suplemen Makalah Lengkap Kongres Nasional VIII Perinasia \& Simposium International, 2003

16. Tiran, Denise. Bailliere's Midwives Dictionary. Kamus Saku Bidan (Alih Bahasa: Hartono, Andry). 10 $0^{\text {th }}$ Edition. London: Oxford United Kingdom. 2003

17. Ronoatmodjo, Sudarto. Risiko Kematian Neonatal di Kecamatan Keruak Nusa Tenggara Barat 1992-1993 (Disertasi). Depok: FKM-UI, 1996

18. Depkes, Pedoman Pemantauan Wilayah Setempat Kesehatan Ibu dan Anak (PWS-KIA). Jakarta: Depkes RI, 2004

19. Wiknjosastro, Hanifa. Ilmu Kebidanan Edisi ketiga, Jakarta: Yayasan Bina Pusataka Sarwono Prawirohardjo, 1991

20. Mochtar, Rustam, Sinopsis Obstetri. Jilid 2, Jakarta: EGC, 1998

21. Oswyn, Vince and Friesen, Perinatal Asphyxia at Port Moresby General Hospital: a Study of Incidence, Risk Factors \& outcome. Papua New Guinea Medical Journal. Vol. 43. No. 1-2, Mar_Jun. 2000

22. Yunanto, Ari; Djallalluddin; M Arifin Fahmi. Pengaruh Berat Bayi Lahir Rendah untuk Terjadinya Asfiksia Neonatorum di Rumah Sakit Umum Ulin Banjarmasin 2002-2003. Medan: Suplemen Makalah 
Lengkap Kongres Nasional VIII Perinasia \& Simposium International, 2003.

23. Rini K.E, Anky Tri. Evaluasi Pelaksanaan Metode Kanguru Pada Bayi Berat Lahir Rendah (BBLR) Pasca Perawatan Intensif Neonatus. Medan: Suplemen Makalah Lengkap Kongres Nasional VIII Perinasia
\& Simposium International, 2003

24. Djelantik, IG.G Perawatan Bayi Baru Lahir dengan Metoda Kanguru (Kangaroo Mother Care Programe). Medan: Suplemen Makalah Lengkap Kongres Nasional VIII Perinasia \& Simposium International, 2003 